\title{
Effectivity Of Agroedutourism To Strengthen Healthy Agro-Ecosystem Awareness Of Students In Some Elementary Schools In Malang Raya, East Java
}

\author{
Hanin Niswatul Fauziah ${ }^{1}$, Endang Arisoesilaningsih ${ }^{2}$ and Bagyo Yanuwiadi ${ }^{2}$ \\ ${ }^{1}$ Biology Postgraduate Program, Biology Department, Faculty of Mathematics and Natural Sciences, \\ Brawijaya University, Malang, Indonesia \\ ${ }^{2}$ Biology Department, Faculty of Mathematics and Natural Sciences, Brawijaya University, Malang, Indonesia
}

\begin{abstract}
This research aimed to study the effectivity of agroedutourism to strengthen students' environmental awareness, especially concerning on importance of rice organic farming system. Eighty three students were invited joining the program. They were the $5^{\text {th }}$ grade of three elementary schools (SDN Ketawanggede 2, SDI Surya Buana and SDN Sumberngepoh 02). It was provided three agroedutourism programs, i.e. two outdoors programs (Farmers' friends and enemies, Plants for biopesticide and natural attractant), as well as the indoor session called Healthy agroecosystem. Including the programs were joining ecoeco-games and tasting some food (steamed rice-bran brownies, organic red rice milk and zalacca fruits). Effectivity of the programs was evaluated using questionnaire. Data were analyzed by SPSS program using Wilcoxon test $(\alpha=0,05)$. Results showed overall that the agroedutourism increased significantly students cognitive, affective and even their appreciation to agricultural environment. Students of SDN Sumberngepoh 02 showed a highest agro-environmental awareness. While, the highest cognitive improvement was gained by students of SDI Surya Buana (76\%), followed by SDN Ketawanggede $2(62 \%)$ and SDN Sumberngepoh $02(47 \%)$. The most interesting program was an outdoor namely Farmers' friends and enemies, while they preferred a steamed rice-bran brownies than the other one. They were exciting joining some eco-games especially predator and prey as well as guest animal name and its role. It seemed that the outdoor programs were more appreciated rather than the indoor one.
\end{abstract}

Keywords: Agroedutourism, awareness, effectivity, healthy agro-ecosystem

\section{INTRODUCTION}

"Program Indonesia Sehat 2025" is the government's efforts to improve life quality of Indonesian's people. One of the factors that affect the quality of human life is the environment quality $[3,6.1]$. Environmental quality is a resultant of the constituent parts of a environment quality [3] and measured by the quality of water, air, soil, and biodiversity [7]. Environmental quality expected in "Program Indonesia Sehat 2025" is good environment quality, its means that the environment should be free from pollution and other environmental problems [1]. Environmental problems that occurred in Indonesia has caused environmental degradation. These environmental problems occur due to various factors such as: population growth, urbanization, agricultural intensification, etc [2]. Some of the environmental issues that

\footnotetext{
Corresponding Address: Hanin Niswatul Fauziah

Email : haninhusein@gmail.com

Address : Biology Postgraduate Program, Biology

Department, Faculty of Mathematics and Natural Sciences, Brawijaya University, Jl. Veteran, Malang
}

Indonesia facing are: deforestation, global warming, air, soil and water pollution. Air, soil and water pollution in Indonesia come from agricultural sector due to use of synthetic pesticides and chemical fertilizers. The use of synthetic pesticides and chemical fertilizers due to a low of Indonesian's people understanding of environmental conservation. Considering that Indonesia is agricultural country and most of Indonesian's people livelihood are farmer, therefore required an effort to improve understanding of environmental conservation. Formal environmental education in elementary school was still not optimal to improve students understanding on environmental conservation due to the theoretical materials, not discussing the real problems and had not involved local people participation. Therefore it is necessary to improve environmental education to be more applicable and involving real problem and community participation, for example by enjoyfull learning namely agroedutourism. This study aimed to study the effectivity of agroedutourism to improve the understanding of environmental conservation. 


\section{METHOD}

Target of this study were $5^{\text {th }}$ grade of some elementary school's students such as SDN Ketawanggede 2, SDN Sumberngepoh 02 and SDI Surya Buana. We provided three agroedutourism programs, there were 1). learning on farmer's friends and enemies, 2). learning on plants as raw material for biopesticide and natural attractant and 3). learning on healthy agroecosystem. Each agroedutourism program was composed by some activities such as discussion, eco-games and taste of healthy food. Before program implementation, students preliminary understanding was evaluated by first questionnaires. Then students learnt organic farming from leaflet and it was continued by main program of agroedutourism. After students tasted food, namely steamed rice bran brownies, zalacca fruit and red rice milk and continued by following eco-games. Finally overall achievement were determined from second questionnaires. Effectivity of agroedutourism known by Wilcoxon $(\alpha=5 \%)$ test to questionnaire 1 and 2 .

\section{RESULTS AND DISCUSSION}

All students were excited following agroedutourism programs that were provided (Figure 1). It was due to agroedutourism programs concept were playing while learning. Nevertheles, students's exciting degrees in each agroedutourism programs were different. Students that following agroedutourism program in paddy field more excited than in school yard and class room, while students in school yard more excited than in class room. It was due to students that following agroedutourism program in class room want to join agroedutourism program in outdoor. From three types of food that was provided, students prefered bran brownies than the other one, because bran brownies more delicious than the other one and from three eco-games that provided students prefered predator and prey as well as guest animal name and its role than the other one (Figure 2).

Before agroedutourism program, average value of three elementary school students's cognitive competencies ranged between 1- 1.38; affection between $3.48-4.12$ and appreciation between 3.44 - 4.10. After agroedutourism program average value of students cognitive competence increased be 1.76 - 1.85; affection be $3.88-4.77$ and appreciation be $3.80-4.74$ (Figure 3). It showed that agroedutourism effective to improve students's understanding.

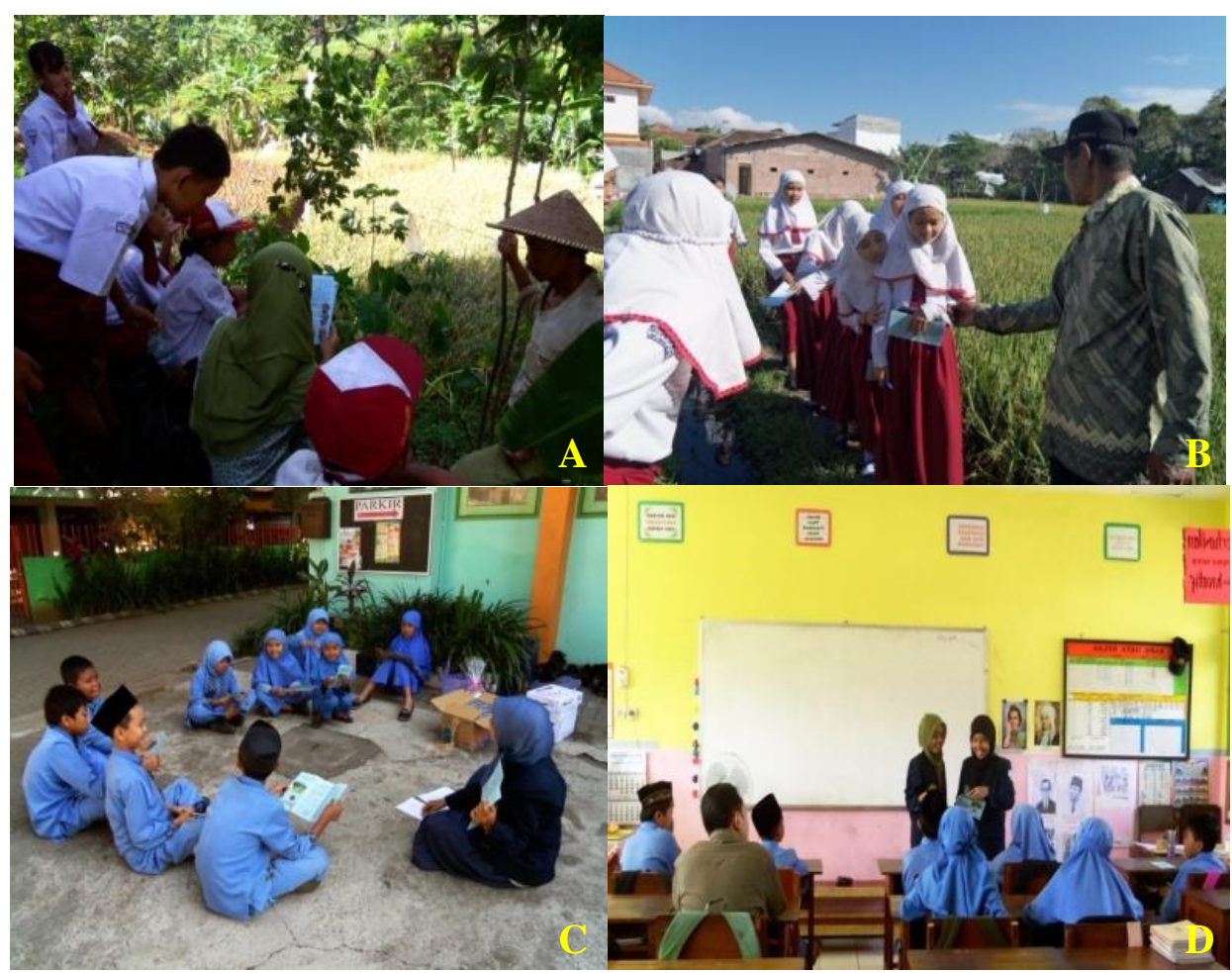

Figure 1. Argoedutourism programe at three different location (A\&B) field, (C) school yard and (D) class 


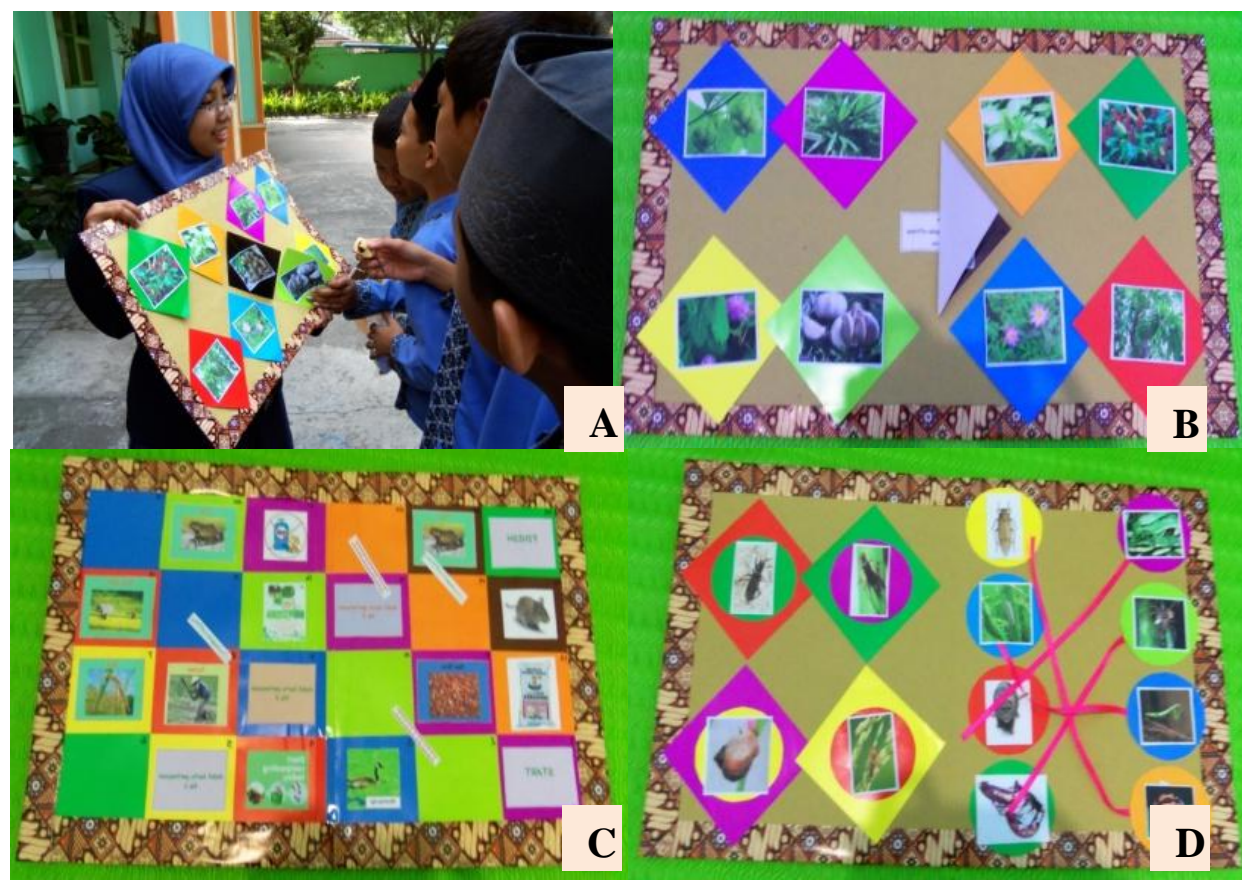

Figure 2. Eco-games at agroedutourism program (A) predator and prey as well as guest animal name and its role (B) snake and aldder and study healthy agroecosystem (C\&D) guest plant name and its function

Although agroedutourism could improve students's understanding but the understanding of each school students were not same. This difference showed that understanding level of agroedutourism program that acceptanced by each students were not same. It was due to differences of environmental factors, intelligence level and students' attention to agroedutourism program. There are two factors that influenced student learning outcomes, namely internal factors and external factors. Internal factors include motivation, attention and the students response in activity, while external factors were environmental and family factors [10]. Before agroedutourism, the highest cognitive competence, affection and appreciation was students of SDN Sumberngepoh 02, following by students of SDN Ketawanggede 2 and students of SDI Surya Buana, as well as cognitive competence, affection and appreciation of the students after agroedutourism.

Students of SDN Sumberngepoh 02 had the highest cognitive competence, affection and appreciation due to majority of student parents were farmers and living in rural, while majority of student parents of SDN Ketawanggede 2 and SDI Surya Buana were enterpreneur and lived in urban areas. The higher cognitive competence of SDN Sumberngepoh 02's students cause the students affection and appreciation were higher than the other one. Children who has been living in the village and their parents' professions were farmers will had higher agricultural knowledge than children who live in urban areas. Children's cognitive competence were formed from what were they seen and heard daily. Beside influenced by environmental factors, cognitive competence was also influenced by parents behavior, because parents had an important role in children's cognitive development. Parents's behavior were often imitated by children, so children learnt from his parents activities. In rural areas, parents often taking their children to paddy fields and some time their parents ask the children to help their work. Thereby children can learn directly from nature by imitating their parents behavior and it will made them more concerned to agricultural environment. According to Carl Rogers, cognitive competence was one of the factors that influence affection and appreciation [8]. Person knowledge will affect person's affection and appreciation.

Students of SDI Surya Buana had the lowest cognitive competence, affection and appreciation than students of SDN Sumberngepoh 02 and SDN Ketawanggede 2 . It was caused by majority parents background as enterpreneur, lecturers and live in urban areas. Low of students cognitive competence to agriculture caused low of students affection and appreciation to environmental conservation. In the opinion of some psychologists, the environment is one of 
factor that affects person's cognitive competence and good cognitive competence will affect good affections [4,9,5]. Environment where these students live is a place of learning for children before school, so good environmental conditions will produce a better appreciation as well.

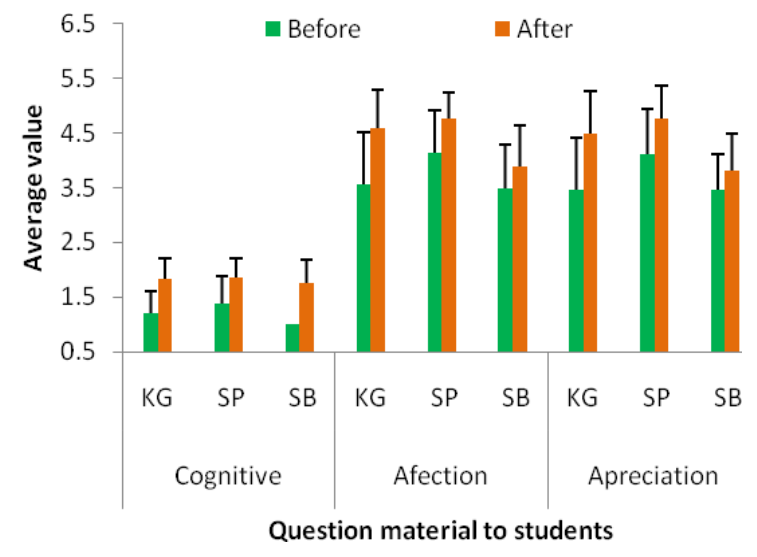

Figure 3. Variability of cognitive, affective and apreciation before and after agroedutourism programe Notice: $K G=$ SDN Ketawanggede 2; $\mathrm{SP}=\mathrm{SDN}$ Sumberngepoh 02; SB= SDISurya Buana. *Different notation indicate a significant difference at significacnce level of $5 \%$.

Students of SDI Surya Buana had the largest percentage increase in cognitive competence were $76 \%$ (from 1 to 1.76), then students of SDN Ketawanggede with percentage increase $62 \%$ (from 1.21 to 1.83 ) and the last was students of SDN Sumberngepoh 02 by percentage increase $47 \%$ (from 1.38 to 1.86). Students of SDN Sumberngepoh 02 had the lowest of percentage increase on cognitive competence, due to students cognitive competence before agroedutourism already high, so when applied agroedutourism program the cognitive competence increasing were not high as another school. While the student of SDI Surya Buana and SDN Ketawanggede 2 cognitive competence before agroedutourism were lower than SDN Sumberngepoh 02 so when applied agroedutourism program, cognitive competence increasing of both schools were greater than SDN Sumberngepoh 02 . The high percentage increase of cognitive competence showed that students gived attention during the agroedutourism program so they could received the material presented by the facilitator.

Students of SDN Ketawanggede 2 had the highest affection percentage increase were $28.56 \%$ (from 3.56 to 4.59 ) and than students of
SDN Sumberngepoh 02 were $12.23 \%$ (from 4.25 to 4.77 ) and the lowest were students of SDI Surya Buana were $11.49 \%$ (from 3.48 to 3.88 ), as well as percentage increase of appreciation. Students of SDN Ketawanggede 2 appreciation increased were $29.36 \%$ (from 3.46 to 4.49), students of SDN Sumberngepoh 02 increasing were $15.60 \%$ (from 4.10 to 4.75 ) and students SDI Surya Buana increasing were 7, 5\% (from 3.44 to 3.81). Students of SDN Ketawanggede 2 had the highest percentage increasing of affection and appreciation than students of SDN Sumberngepoh 02 and students of SDI Surya Buana. The high percentage increasing students affection and appreciation of SDN Ketawanggede 2 due to the high of students's cognitive competence. The higher students cognitive competence would influenced the higher of students affection and appreciation. According to Sageofasheville (2012) cognitive competence is one of the factors that influenced of affection, and affection is one of the factors that influenced of appreciation. Students of SDI Surya Buana had the lowest percentage increasing of affection and appreciation altough students's cognitive competence students of SDI Surya Buana with SDN Sumberngepoh 02 and SDN Ketawanggede 2 were almost same. This is presumably due to the students cognitive competence of SDI Surya Buana still could not enter into the soul, so students just know it and not yet understand it. Therefore, the students cognitive competence of SDI Surya Buana could'nt improve students's affection and appreciation.

\section{CONCLUSION}

Agroedutourism effective to improve students's understanding of the importance of environmental conservation, this can be seen from the increasing of cognitive competence, affection and appreciation of students's to environmental conservation. The most effective agroedutourism program to improve students's understanding of the importance of environmental conservation was study farmer's friends and enemies.

\section{ACKNOWLEDGMENTS}

We would like to express a sincerely gratitude to Dr. Endang Arisoesilaningsih for funding this study, SDN Ketawanggede 2, Sumberngepoh 02 and SDI Surya Buana for supporting study and people who help us for study

\section{REFERENCES}


[1] Departemen Kesehatan RI, (2009), Rencana Pembangunan Jangka Panjang Bidang Kesehatan 2005 2025. http://www.depkes. go.id. Accesed on 12 February 2012.

[2] Indiabudget, (2012), Industrial Pollution. http://www.indiabudget.nic.in. Accesed on 20 February 2012.

[3] Kampt I.V., Leidermeijer K., Marsman G and Hollander A. (2003), Urban environmental Quality and Human Well-Being Toward a Conceptual Framework and Democration of Concept: a Literature Study. Landscape and Urban Planning., 65,5-18.

[4] Kramer, A.F., Bhere L., Colcombe S.J., Dong W., and Greenough W.T., (2004), Environmental Influences on Cognitive and Brain Plasticity During Aging. Journal of Gerontology: Medical Sciences. 59A, 9, 940957.

[5] Mac, (2012), How Do Children Learn? Theories About Child Development And Learning. http://web.mac.com. Accesed on 22 June 2012.

[6] Pacione, M., (2003), Urban Environmental Quality and Human Wellbeing a Social Geographical Perspective. Landscape and Urban Planning 65,19-30.

[7] Piie, (2011) Labor And Environmental Issues in Indonesia. http://www.piie.com/publications/chapters_preview/4020/04iie4020.p df. Accesed on 12 February 2012.

[8] Sageofasheville, (2012) Carl Rogers and Humanistic Education. http://www.sageo fasheville.com/. Accesed on 22 June 2012.

[9] Simatwa E.M.W., (2010), Piaget's Theory of Intellectual Developments And Its Implication for Instructional Management at Pre Secondary School Level. Educational Research and Review 5, 7, 366-371.

[10] Sucihatiningsih dan Sulistyowati H., (2010), Faktor-Faktor yang Mempengaruhi Kesulitan Belajar Mata Pelajaran IPS Ekonomi. 162181. 